\title{
Oilseeds ameliorate metabolic parameters in male mice, while contained lignans inhibit 3T3-L1 adipocyte differentiation in vitro
}

\author{
Giorgio Biasiotto $\cdot$ Marialetizia Penza Isabella Zanella • \\ Moris Cadei - Luigi Caimi - Cristina Rossini • \\ Annika I. Smeds • Diego Di Lorenzo
}

Received: 9 September 2013/ Accepted: 2 February 2014

(C) Springer-Verlag Berlin Heidelberg 2014

\begin{abstract}
Purpose and background The focus was directed to the study of two of the most lignan-rich food sources: sesame and flaxseeds. Recent epidemiological and experimental evidences suggesting that these foods may improve metabolic functions underlying metabolic syndrome (MetS).

Methods To characterize the effect of these oilseeds on metabolic functions, we conducted an experimental study aimed at preventing adiposity and metabolic imbalance in a mouse model of high-fat diet (HFD)-induced MetS. Statistical analysis was performed by two-way analysis of variance test followed by post hoc Bonferroni analysis.

Results We studied the effect of the oilseeds sesame and flaxseed on metabolic parameters in mice on a HFD. When
\end{abstract}

Giorgio Biasiotto and Marialetizia Penza have contributed equally to this work.

G. Biasiotto · M. Penza · I. Zanella · L. Caimi

D. Di Lorenzo $(\square)$

Biotechnology/3rd Laboratory, Civic Hospital of Brescia,

25123 Brescia, Italy

e-mail: diego.dilorenzo@yahoo.it

G. Biasiotto · I. Zanella $\cdot$ L. Caimi

Department of Molecular and Translational Medicine,

University of Brescia, Brescia, Italy

M. Cadei

Human Pathology II, School of Medicine, University of Brescia,

Brescia, Italy

C. Rossini

Department of Pathology I, School of Medicine,

University of Brescia, Brescia, Italy

A. I. Smeds

Laboratory of Wood and Paper Chemistry, Åbo Akademi

University, Turku, Finland the HFD was integrated with $20 \%$ of sesame or flaxseed flours, the mice showed a decrease in body fat, already at day 15 , from time 0 . The size of the adipocytes was smaller in epididymal fat, liver steatosis was inhibited, and insulin sensitivity was higher in mice on the supplemented diets. The supplemented diets also resulted in a significant increase in the serum levels of the lignan metabolites enterodiol and enterolactone compared with the controls. The expression of genes associated with the inflammatory response, glucose metabolism, adipose metabolism and nuclear receptor were altered by the oilseed-supplemented diets. Some of the most abundant lignans in these oilseeds were studied in 3T3-L1 preadipocyte cells and were effective in inhibiting adipocyte differentiation at the minimal dose of $1 \mathrm{nM}$.

Conclusions The consumption of sesame and flaxseed may be beneficial to decrease metabolic parameters that are generally altered in MetS.

Keywords Oilseeds - Lignans - Metabolic syndrome · Adipose deposition $\cdot 3 \mathrm{~T} 3-\mathrm{L} 1$ differentiation

\section{Introduction}

Lignans are chemicals produced as secondary metabolites in plants where they are found mostly as aglycones, oligomers and glycosides [1,2]. Their structure is determined by the union of two cinnamic acid residues or their biogenetic equivalents. They occur in the whole plant kingdom and can also be found in fiber-rich foods, typically regarded as healthy foods. Dietary lignans are broadly available and particularly concentrated in oilseeds (especially in flaxseed and sesame), in cereal grains (e.g., wheat and rye bran) and nuts [3], Brassica species, legumes, 
berries, and in many plant-related beverages (tea, coffee, wine) [1, 4-7]. Cereal brans, legumes and some seeds and vegetables are suggested to be the most important sources of lignans in the EU diets [8]. The average lignan intake in the Finnish population (food frequency questionnaires: $n=2,862)$ was estimated to be $434 \mu \mathrm{g} /$ day $(285 \mu \mathrm{g} /$ day for men and $601 \mu \mathrm{g} /$ day for women) [9]. In a Dutch study (food frequency questionnaires: $n=4,660$ ), the average daily intake of lignans was calculated to be $1,241 \mu \mathrm{g} /$ day [1]. Intakes between 850 and $5,816 \mu \mathrm{g} /$ day have been determined in central-south EU [10] and $760 \mu \mathrm{g} /$ day in Spain [11]. Higher intakes (up to $13.5 \mathrm{mg} /$ day) have been found in Germany [12]. Lignans are expected to have beneficial effects in humans after fermentative conversion in the colon to the mammalian lignans ENL and END [13, 14]. Subpopulations with higher consumption of lignans display considerable lower disease frequency [7, 15-22]. In several studies, lignan-rich foods, concentrates or partially purified compounds have been shown to improve blood lipids, to enhance glycemic control and to alleviate or cure type 1 and type 2 diabetes [23-27]. However, the results produced in these studies, although very promising, were not homogeneous due to their different and often fragmented approaches. The identified variables were as follows: the source of the lignans and other factors in the food, the doses of compounds in different preparations (extracts or whole grains), the time of intake, the targeted cohorts, the analyzed end-points and the methods of analysis [28]. Some mechanistic studies have also been performed identifying the lignans mainly as efficient antioxidants and phytoestrogenic compounds [29-31].

The present work is based on recent epidemiological and experimental evidences, suggesting that lignan-rich foods, such as oilseeds, may improve metabolic functions underlying metabolic syndrome (MetS) [17, 22, 29, 32-34]. The focus was directed to study two of the most lignan-rich food sources: sesame and flaxseeds, which contain up to $1 \%$ lignans $(500-1,000 \mathrm{mg} / 100 \mathrm{~g})[35,36]$. Sesame seeds contain several lipophilic (sesamin (SES), sesaminol, sesamolinol and sesamolin), as well as hydrophilic lignans [7hydroxymatairesinol, pinoresinol (PIN), medioresinol (MED), matairesinol (MR), lariciresinol (LAR), cyclolariciresinol (CLAR), $\alpha$-conidendrin and 7-oxomatairesinol], while flaxseed contains mainly secoisolariciresinol diglucoside, which composes $98 \%$ of the lignans in this seed [36]. A few other lignans have recently been identified in food sources, of which, to our knowledge, no biological studies have been conducted: for example todolactol A [3, 37], saminol and episesaminone sophoroside [37], secoisolariciresinol (SEC) and lariciresinol sesquilignans and iso-hydroxymatairesinol (iso-HMR) [3].

To characterize the effect of these oilseeds on metabolic functions at the basis of MetS, we conducted an experimental study in a mouse model of HFD-induced MetS. Furthermore, the most concentrated hydrophilic lignans in the studied materials were characterized as single molecules in a cellular model of induced adipogenesis.

\section{Materials and methods}

\section{Experimental animals}

The procedures involving animals and their care were conducted in accord with institutional guidelines, which comply with national and international laws and policies (National Institutes of Health, Guide for the Care and Use of Laboratory Animals, 1996 (7th ed.) [Washington, DC]; National Academy Press, National Research Council Guide, www.nap.edu/ readingroom/books/labrats). Three-week-old C57BL/6J male mice (Harlan, Udine) were kept in animal rooms maintained at a temperature of $23{ }^{\circ} \mathrm{C}$, with natural light/dark cycles. The animals were killed by cervical dislocation, and the tissues were dissected and immediately frozen on dry ice.

\section{Diets}

Low-fat (LFD) and high-fat (HFD) diets containing 10 and $50 \%$ fat, respectively, were purchased by Piccioni (Milan, Italy). Importantly, a careful calculation of the final total fat present in the diets was made. The sesame-supplemented diets (SSD) and flaxseed-supplemented diets (FSD) were isocaloric and prepared to contain the same amount of total fat as for the HFD. The different amount of calories of sesame and flaxseed was compensated by adjusting the component of lard (Table 1).

\section{Chemicals and seeds}

The lignans SEC, PIN, CLAR and LAR were prepared at Åbo Akademi University (Laboratory of Wood and Paper Chemistry) as described previously [3], and SES was from Sigma (Pomezia, Italy). The chemicals were dissolved in DMSO and further diluted before their addition to the 3T3L1 culture medium, for homogeneous preparations. The seed samples were obtained from: "Il Campicello del Biologico and Biopack s.a.s. (Turin, Italy)". Table 2 lists the composition of sesame and flaxseed. The specific lignans composition is described in Table 3, and it is in accordance with quantification reported in the literature [38].

\section{EchoMRI analysis}

Echo Magnetic Resonance Imaging system (EchoMRI) (Medical System, Houston, TX), provides the most precise measurements of whole body composition parameters 
Table 1 Composition of diets fed to mice for 84 days

\begin{tabular}{llll}
\hline $\begin{array}{l}\text { Low-fat diet } \\
(10 \% \text { calories from fat })\end{array}$ & $\begin{array}{l}\text { High-fat diet } \\
(50 \% \text { calories from fat })\end{array}$ & $\begin{array}{l}\text { High-fat diet plus } 20 \% \\
\text { sesame }\end{array}$ & $\begin{array}{l}\text { High-fat diet plus } 20 \% \\
\text { flaxseed }\end{array}$ \\
\hline $20.0 \%$ casein & $25.0 \%$ casein & $19.5 \%$ casein & $19.0 \%$ casein \\
$0.3 \%$ L-cysteine & $0.3 \%$ L-cysteine & $0.3 \%$ L-cysteine & $0.3 \%$ L-cysteine \\
$25.0 \%$ mais starch & $10.8 \%$ mais starch & $6.2 \%$ mais starch & $6.0 \%$ mais starch \\
$8.5 \%$ maltodextrins & $5.0 \%$ maltodextrins & $5.0 \%$ maltodextrins & $5.0 \%$ maltodextrins \\
$31.5 \%$ sucrose & $20.5 \%$ sucrose & $23.0 \%$ sucrose & $21.0 \%$ sucrose \\
$5.0 \%$ cellulose & $5.0 \%$ cellulose & $3.3 \%$ cellulose & $4.6 \%$ cellulose \\
$2.5 \%$ mais oil & $2.5 \%$ mais oil & $2.5 \%$ mais oil & $2.5 \%$ mais oil \\
$2.0 \%$ lard & $13.0 \%$ Lard plus $12.5 \%$ hydrogenated coconut Oil & $14.8 \%$ lard & $16.2 \%$ lard \\
$4.0 \%$ mineral mix & $4.0 \%$ mineral mix & $4.0 \%$ mineral mix & $4.0 \%$ mineral mix \\
$1.0 \%$ vitamin mix & $1.0 \%$ vitamin mix & $1.0 \%$ vitamin mix & $1.0 \%$ vitamin mix \\
$0.2 \%$ colin bitartrate & $0.4 \%$ choline chloride & $0.4 \%$ choline chloride & $0.4 \%$ choline chloride \\
$/$ & $/$ & $20.0 \%$ sesame & $20.0 \%$ flax seed \\
\hline
\end{tabular}

Low-fat (LFD) and high-fat (HFD) diets containing $10 \%$ and $50 \%$ fat, respectively, were purchased from Piccioni (Milan, Italy). Importantly, a careful calculation of the final total fat present in the diets was made

The sesame- and flaxseed-supplemented diets were isocaloric and prepared from Piccioni to contain the same amount of total fat as for the HFD

Table 2 Composition of sesame and flaxseed in percent

\begin{tabular}{lllll}
\hline \multicolumn{2}{l}{ Composition of sesame } & & & \multicolumn{2}{l}{ Composition of flaxseed } \\
\cline { 1 - 1 } \cline { 5 - 5 } Ingredient & Percent & & Ingredient & Percent \\
\hline Water & 8 & & Water & 8 \\
Protein & 22.3 & & Protein & 25 \\
Fat & 42.9 & & Fat & 36 \\
Fiber & 9.0 & & Fiber & 5.5 \\
Ash & 5.6 & & Ash & 4.5 \\
Nitrogen free extract & 12.2 & & Nitrogen free extract & 24.0 \\
Total lignans & 1 & & Total lignans & 0.5 \\
\hline
\end{tabular}

(total body fat and lean mass), in living mice without the need of anesthesia or sedation and in $<1 \mathrm{~min}$. Alterations in mouse whole body composition were assessed as a result of exposure to the diets. Measurements of fat and lean mass and body weight were made twice a week for the whole period of the study.

Standard protocol: The EchoMRI-100 ${ }^{\mathrm{TM}}$ QNMR system was housed in a dedicated area to minimize the entry of disease or contaminants. Prior to each QNMR run, the system was calibrated using a standard provided by Echo Medical System. Each mouse was placed into an appropriate size tube and placed in the QNMR instrument for measurements. The mouse was subjected to a predetermined sequence of radio frequency energy during a $47 \mathrm{~s}$ run. Three sequential independent scans were conducted for each mouse, and the data were automatically transferred to the database. The output information was expressed as lean tissue mass and fat mass in grams.
Table 3 Concentration of lignans in extract of milled flaxseeds and sesame

\begin{tabular}{lll}
\hline Lignan $(\mu \mathrm{g} / 100 \mathrm{~g})$ & Flaxseeds & Sesame seeds \\
\hline Hydroxymatairesinol & nd & 9,021 \\
Secoisolariciresinol & 690,757 & 61.78 \\
Matairesinol & 42.35 & 773.0 \\
Lariciresinol & 335.2 & 5,445 \\
Cyclolariciresinol & 8,260 & 595.0 \\
Pinoresinol & 401.5 & 13,065 \\
Medioresinol & nd & 1,913 \\
Syringaresinol & nd & nd \\
Sesamin & nd & 42,415 \\
a-Conidendrin & 25.21 & 253 \\
7-Oxomatairesinol & nd & 159.6 \\
7-Hydroxysecoisolariciresinol & 997 & nd \\
Secoisolariciresinol sesquilignan & 2,036 & nd \\
Total & 702,854 & 73,701 \\
\hline
\end{tabular}

Insulin tolerance tests

For insulin tolerance tests, fed animals were used. Animals were injected intraperitoneally with $0.75 \mathrm{IU} / \mathrm{kg}$ body weight of soluble insulin (Humulina Regular, Lilly, Madrid). Blood glucose was measured in each sample using an Accu-Chek compact glucometer (Roche Diagnostic GmbH, Mannheim, Germany). Insulin concentration was assayed by a standardized mouse insulin assay (Cat.\# EZRMI-13 K; Millipore, Milan). 
3T3-L1 cell culture

Mouse 3T3-L1 fibroblasts (American Type Culture Collection) were maintained as subconfluent culture by passage every 3 days from culture seeded at 5,000 cells $/ \mathrm{cm}^{2}$ in Dulbecco's modified Eagle's medium (DMEM) containing $10 \%$ calf serum (Invitrogen). Cells were maintained at $37{ }^{\circ} \mathrm{C}$ in a humidified $5 \% \mathrm{CO}_{2}$ atmosphere.

\section{T3-L1 adipocyte differentiation assay}

For differentiation assay, 3T3-L1 cells were seeded at $5 \times 10^{3}$ cells per well into 24 -well tissue culture plates in DMEM containing $10 \%$ calf serum. Two days after having confluence (D0), the cells were treated with vehicle (DMSO or absolute ethanol) or test chemicals such as SEC, LAR, CLAR, PIN and SES, either in basal medium (BAS) (DMEM containing $10 \%$ calf serum) or in differentiation medium (MDI) (DMEM containing $10 \%$ fetal bovine serum, $167 \mathrm{nM}$ insulin, $0.5 \mathrm{mM}$ isobutylmethylxanthine and $1 \mathrm{mM}$ dexamethasone) for 2 days (D2). Cells were then maintained for further 2 days (D4) in BAS or in MDI medium supplemented only with $167 \mathrm{nM}$ insulin. The medium was changed every 2 days. On the day 9 after treatment, adipocyte differentiation was quantified by using the commercially available adipogenesis assay kit (Millipore) according to the manufacturer's instructions. Briefly, cells were stained with Oil Red O solution $(0.36$ in $60 \%$ isopropanol) for $15 \mathrm{~min}$; a wash solution was provided to remove free Oil Red O from the cell layer, and finally, lipid-bound Oil Red $\mathrm{O}$ was extracted with a dye extraction solution and measured at $520 \mathrm{~nm}$ in a spectrophotometer. For each chemical test, three independent experiments were performed. The average of these determinations has been calculated through the appropriated statistical analysis.

Determination of plant lignans in sesame and flaxseed and of enterodiol and enterolactone in mouse serum

The concentration of major hydrophilic lignans present in the sesame and flax seeds from organic cultures (Il Campicello del Biologico and Biopack s.a.s., Turin, Italy) used in the experiments were measured by high-performance liquid chromatography-tandem mass spectrometry (HPLC-MS/MS) [3]. END and ENL were determined by HPLC-MS/MS in the mouse serum samples after enzymatic hydrolysis and solid-phase extraction according to a previously described method [39]. The method was slightly modified by taking $50 \mu \mathrm{l}$ of serum instead of $600 \mu \mathrm{l}$ and 290 units of $\beta$-glucuronidase/sulphatase dissolved in $0.5 \mathrm{ml}$ of $10 \mathrm{mM}$ of sodium acetate buffer $(\mathrm{pH} 5.0)$ for each sample (for the enzymatic hydrolysis).
RNA extraction and expression analysis with TaqMan microfluidic cards

Total RNA was extracted from 10 to $30 \mathrm{mg}$ of tissue using the RNeasy Lipid Tissue Kit (Qiagen, Maryland, USA) and following the manufacturer's instruction. RNA purity and integrity was assessed with denaturing gel electrophoresis. RNA for each sample was reversed transcribed using highcapacity cDNA Archive Kit (Applied Biosystems, Foster City, CA) with a master mix containing $2.5 \mathrm{U} / \mu \mathrm{l}$ of MultiScribe reverse transcriptase and $1 \mu \mathrm{g}$ of total RNA. The reaction mixture was incubated at $25^{\circ} \mathrm{C}$ for $10 \mathrm{~min}$, followed by $120 \mathrm{~min}$ at $37^{\circ} \mathrm{C}$, and then heat inactivation of the enzyme at $85{ }^{\circ} \mathrm{C}$ for $5 \mathrm{~s}$. Two microliters of singlestranded cDNA were mixed with $48 \mu \mathrm{l}$ of nuclease-free water and $50 \mu$ l of TaqMan Universal PCR Master Mix. After loading $100 \mu \mathrm{l}$ of the sample-specific PCR mixture into one sample port of the microfluidic cards, the cards were centrifuged twice for $1 \mathrm{~min}$ at $280 \mathrm{~g}$ and sealed to prevent well-to-well contamination. The cards were placed in the microfluidic card Sample Block of an ABI Prism 7900 HT Sequence Detection System (Applied Biosystems). The thermal cycling conditions were $2 \mathrm{~min}$ at $50^{\circ} \mathrm{C}$ and $10 \mathrm{~min}$ at $95^{\circ} \mathrm{C}$, followed by 40 cycles of $30 \mathrm{~s}$ at $97{ }^{\circ} \mathrm{C}$ and $1 \mathrm{~min}$ at $59.7^{\circ} \mathrm{C}$. The assay for each gene was carried out in triplicate. The calculation of the threshold cycle $(\mathrm{Ct})$ values was performed using the SDS 2.2 software (Applied Biosystems), after automatically setting the baseline and the threshold. The 96 genes Low density Array (LDA) cards were designed containing key genes of metabolic pathways involved in adipose and glucose metabolism, inflammation and nuclear receptor signaling. 18S RNA was used as the reference housekeeping gene. Specific oligonucleotide pairs were designed by the Applied Biosystems service.

\section{Histological examination}

Epididymal adipose tissue was fixed in formaldehyde and embedded in paraffin. Three-micrometer sections were dewaxed and rehydrated through decreasing alcohol series up to distilled water and stained with hematoxylin-eosin to examine cellular architecture and lipid vacuoles. Original magnification was $40 \times$. A pathologist blinded to the treatment groups conducted a histological analysis of the liver sections. Fat content in the liver was quantified by the adipogenesis assay kit (Millipore). Adipocyte size was quantified measuring the cell area using dedicated software (Image Pro Plus; Imaging and Computer, Milan). In all samples, five different fields of the same tissue section were evaluated. Data represent the average results of five different mice. Data are shown as mean \pm SD. 

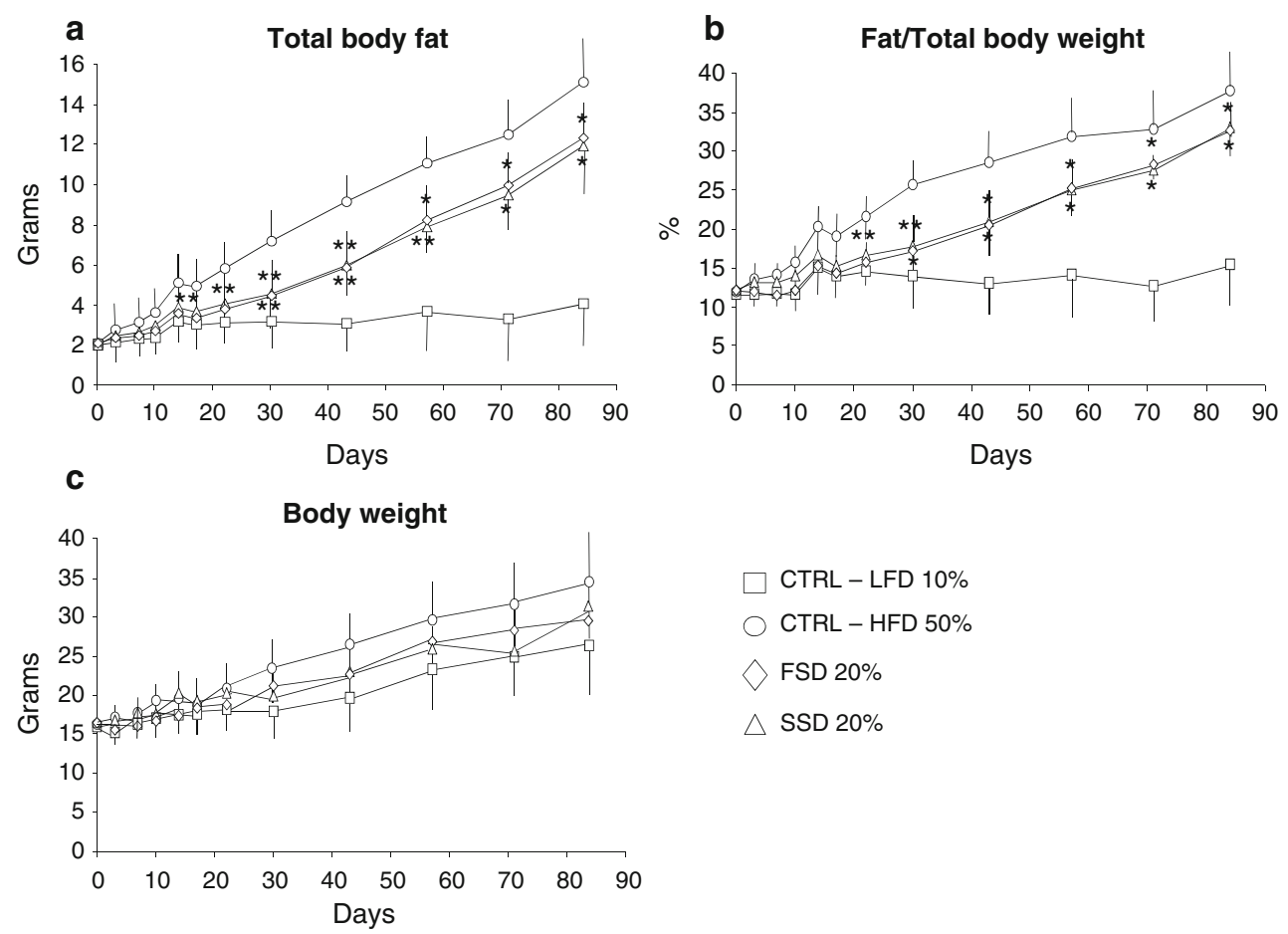

Fig. 1 Effect of sesame- and flaxseed-supplemented diets on fat development in male mice. Time course effects of control LFD, control HFD, $20 \%$ sesame containing diet SSD and $20 \%$ flaxseed containing diet FSD on total adipose tissue development, in 3-weeksold male C57BL/6J mice. Adipose tissue development was analyzed using an EchoMRI system (Huston, TX). a Total body fat. b Adipose tissue development normalized on total body weight (grams of fat/ grams of total body weight). c Body weight. Time of treatments

\section{Statistical analysis}

Statistical analysis of the in vivo data was performed by twoway analysis of variance test followed by post hoc Bonferroni analysis. In vitro data were analyzed by one-way analysis of variance (ANOVA) comparing to the control.

\section{Results}

Effects of oilseed-supplemented diets on body fat deposition in male mice

Three-week-old male mice were exposed to a low-fat diet (LFD $10 \%$ ), a high-fat diet (HFD $50 \%$ ) or a high-fat diet containing $20 \%$ sesame (SSD) or $20 \%$ flaxseed (FSD) flours. Total body fat and total body weight were measured periodically for 84 days. From day 3 until the end of the experiment, the fat mass was significantly lower in mice fed the SSD or FSD diets compared to the mice on the HFD (Fig. 1a). The same result was obtained when fat mass was normalized to the body weight (Fig. 1b). Weak differences were observed in the lean mass and body weight (slightly

84 days. Data represent the average of total fat weight from 10 mice per group $\pm \mathrm{SE}, p<0.05$, or $<0.001$ as compared with the fat mass of mice on the HFD alone. At all the measured time points, the difference between total fat in mice fed the HFD is significant with respect to the mice on the LFD $(p<0.001)$ starting from day 15 (square LFD; circle HFD; triangle HFD plus $20 \%$ sesame flour; rumble HFD plus $20 \%$ flaxseed flour)

decreased in mice fed the supplemented diets), which however did not reached statistical significance (Fig. 1c). Food consumption was not significantly different among the groups (not shown).

\section{Effects of oilseed-supplemented diets on single fat pads}

To confirm the results observed through the measurement of total fat mass by EchoMRI, we also isolated and weighed epididymal and renal fat pads in the same animals that undergo killing. The data shown in Fig. 2 (Fig. 2a, b) confirm that the epididymal and renal fat pads are significantly smaller in the SSD- and FSD-treated mice compared to the mice on the HFD alone. Insulin sensitivity was improved and the need of insulin production and secretion decreased in the oilseed-treated compared to vehicle-treated mice (Fig. 2c, d). Histological examination of the adipocyte size in epididymal fat revealed that the decrease in fat weight of mice fed the SSD or FSD diets, correspond to a decreased cell volume (Fig. 3a). Adipocyte size was quantified measuring the cell area using suitable software. In all samples, five different fields of the same tissue section were evaluated (Fig. 3b). Mice on the high-fat diet 
Fig. 2 Effect of sesame and flaxseed integrated diets on epididymal and renal fat weight. At the end of the treatments ( 84 days), the mice were killed and the organs collected. Adipose tissue deposition was analyzed through the weight of a epididymal and $\mathbf{b}$ renal fat pads. ${ }^{a} p<0.05$ versus $L F D$, ${ }^{\mathrm{c}} p<0.05$ versus HFD. Data represent the average of 10 mice per group \pm SE. c Insulin tolerance test. Awake, HFD fed mice treated with: vehicle (filled circles), sesame (open circles), flaxseed (open squares), were injected intraperitoneally with $0.75 \mathrm{IU}$ of soluble insulin. $n=10$. d Insulin concentration in blood was assayed by a standardized mouse insulin assay a
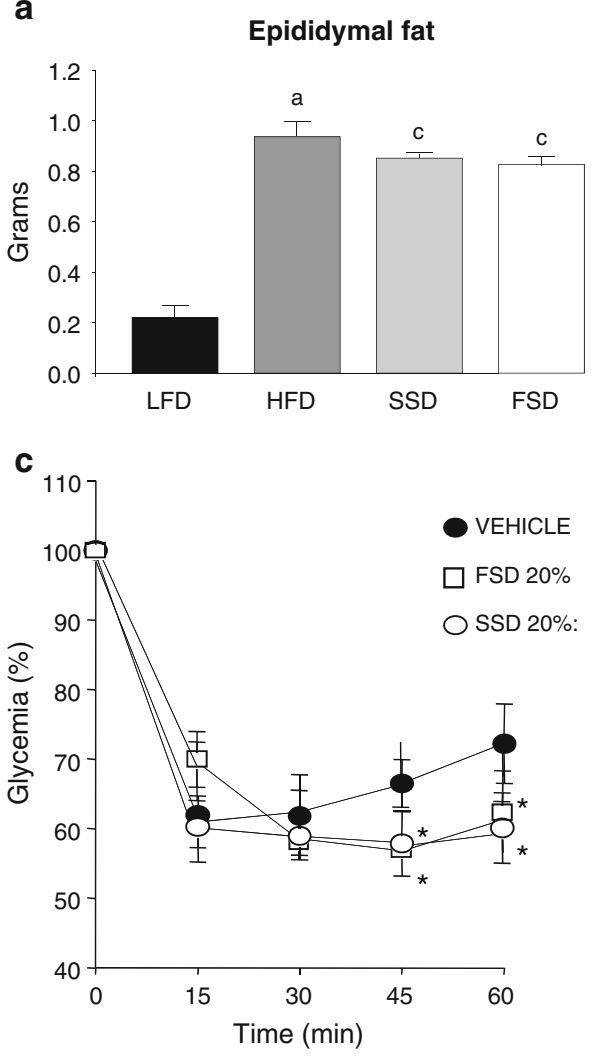

EHICLE
CTRL - LFD 10\%

b

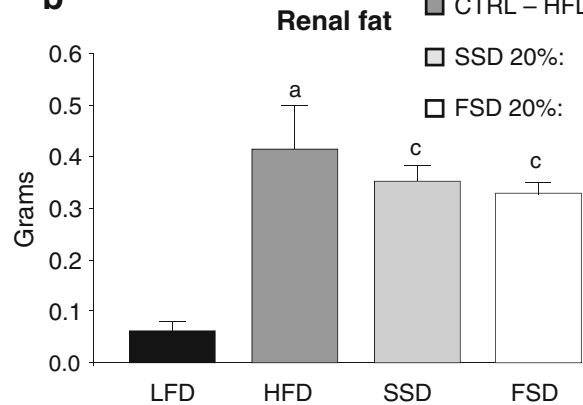

d

Insulin

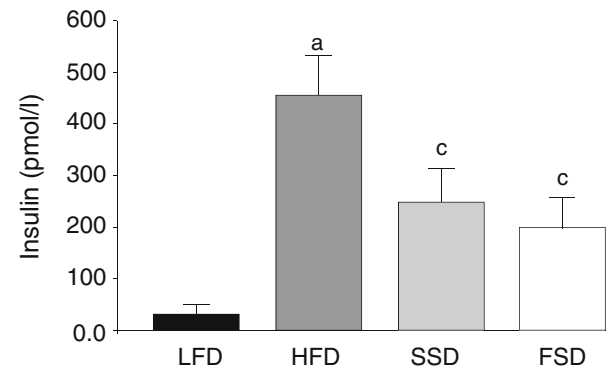

a
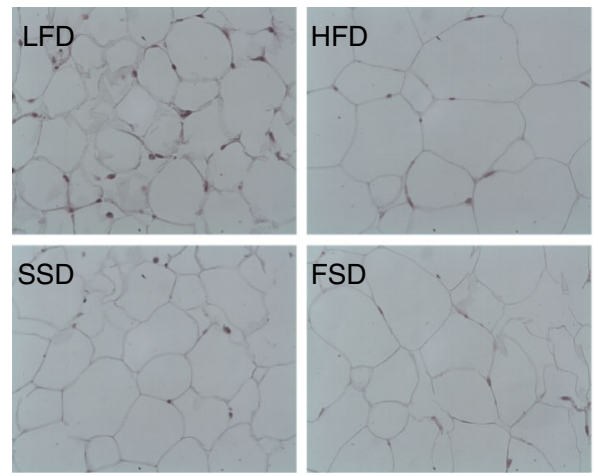

Fig. 3 Histological examination of adipocytes. Epididymal adipose tissue was fixed in formaldehyde and paraffin embedded. Sections $(3 \mu \mathrm{m})$, dewaxed and rehydrated through decreasing alcohol series up to distilled water, were stained with hematoxylin-eosin. a Cells were photographed at $20 \times$ magnification with a digital camera (Nikon

developed accumulation of lipid droplets in the liver (liver steatosis) that were measured by histological analysis (Fig. 4a). Fat content was quantified (Fig. 4b). In the subgroups of mice on the $20 \%$ sesame (SSD) and $20 \%$ flaxseed (FSD) integrated diets, the lipid content in the liver was not significantly different from the liver of mice on the LFD. b

\section{Cell area}

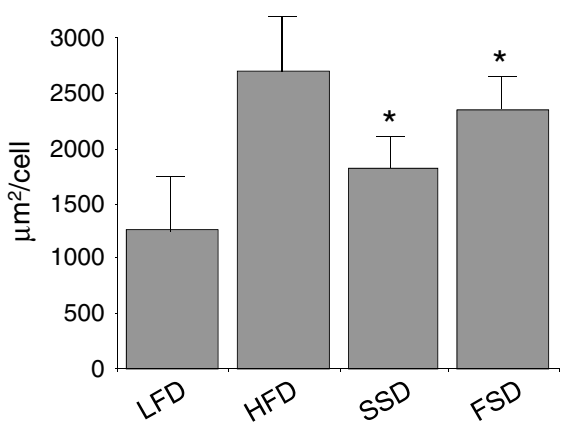

Digital Camera DMX 1200). b Cell area was measured using dedicated software (Image Pro Plus; Imaging and Computer, Milan). In all samples, five different fields of the same tissue section were evaluated. Data represent the average results of five different mice. Data are shown as mean \pm SD. $* p<0.05$

Levels of plant lignans in seed samples and mammalian lignans (ENL, END) in mouse serum

The lignan concentrations present in hydrophilic extracts of the sesame and flaxseeds used in the experiments as assessed by HPLC-MS/MS and shown in Table 3. In flaxseed, the total lignan concentration is $703 \mathrm{mg} / 100 \mathrm{~g}$, in 
a

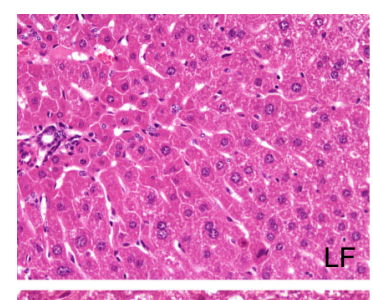

Liver steatosis
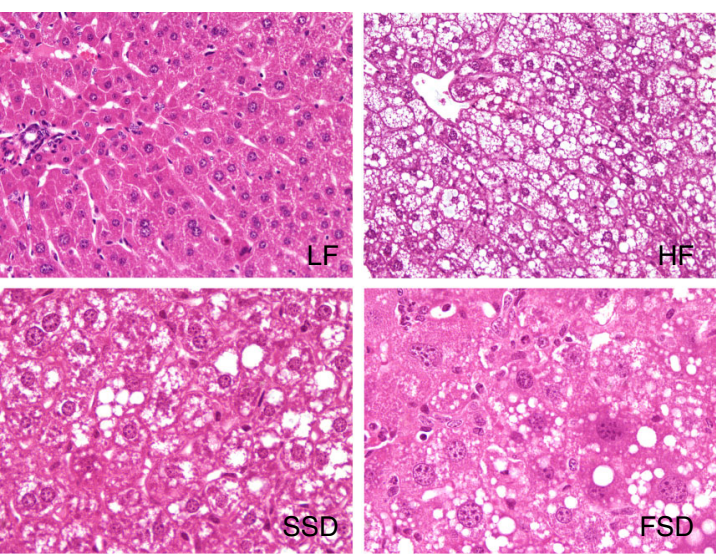

b

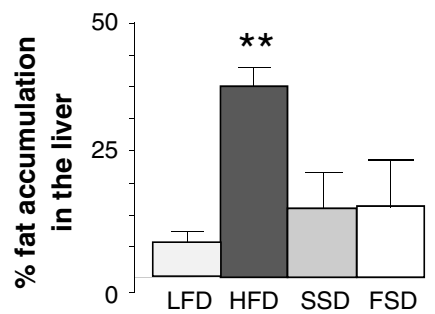

Fig. 4 Liver steatosis. Representative liver sections stained with hematoxylin and eosin. a Livers from LFD-treated mice exhibited normal hepatic architecture, whereas HFD livers revealed micro- and macrovesicular steatosis. SSD and FSD livers show some vacuoles, although much less that HFD mice; b liver tissue was processed for the Adipogenesis assay to quantify the fat content. Percent fat content

sesame $74 \mathrm{mg} / 100 \mathrm{~g}$. It should be noted that sesame seeds are known to contain high concentrations of lipophilic lignans. SES, which is the main lipophilic lignan, was found at the highest lignan concentration of $42,415 \mu \mathrm{g} /$ $100 \mathrm{~g}$ of sesame seeds. A lower amount if compared to its concentration in sesame oil that ranges from 7,000 to $712,000 \mu \mathrm{g} / 100 \mathrm{~g}$ seed [40]. SES is efficiently metabolized in vivo, giving large amounts of mammalian lignans. Nortrachelogenin, lariciresinol sesquilignan and 4,4'dimethyl matairesinol could not be detected in any of the samples. The lignan metabolites ENL and END, produced by the intestinal microbiota from the dietary precursors, were also measured in the mouse serum by HPLC-MS/MS. As reported in Fig. 5, the sera of mice fed the SSD and FSD have significantly higher levels of the metabolites (506 nM END and $336 \mathrm{nM}$ ENL, 1,116 nM END and $113 \mathrm{nM}$ ENL, respectively) compared to the mice on the synthetic LFD (50 nM END and $14 \mathrm{nM}$ ENL) and HFD (46 nM END and $46 \mathrm{nM} \mathrm{ENL).} \mathrm{The} \mathrm{small} \mathrm{amount} \mathrm{of} \mathrm{ENL}$ and END measured in mice on the control LFD and HFD diets probably reflects the consumption of a certain amount of sawdust, which contains several lignans of wood (unpublished) that are metabolized into enterolignans.

\section{Changes in metabolic pathways in the visceral fat}

Increased adipose deposition in visceral fat pads is associated with changes in several metabolic parameters. We analyzed the deregulation of the expression of sets of genes involved in fat accumulation, insulin resistance/glucose metabolism, adipocyte metabolism, inflammation and genes of the nuclear receptors (NRs) family involved in was determined relative to fat content in the liver of mice on the LFD diet. Livers from mice on the HFD diet alone showed 6 times more fat than mice on the LFD diet. Mice on the sesame- and flaxseedsupplemented diet exhibited a fat concentration not significantly different from that of the mice on the LFS diet. Data are shown as mean $\pm \mathrm{SE}(* p<0.05 ; * * p<0.001)$

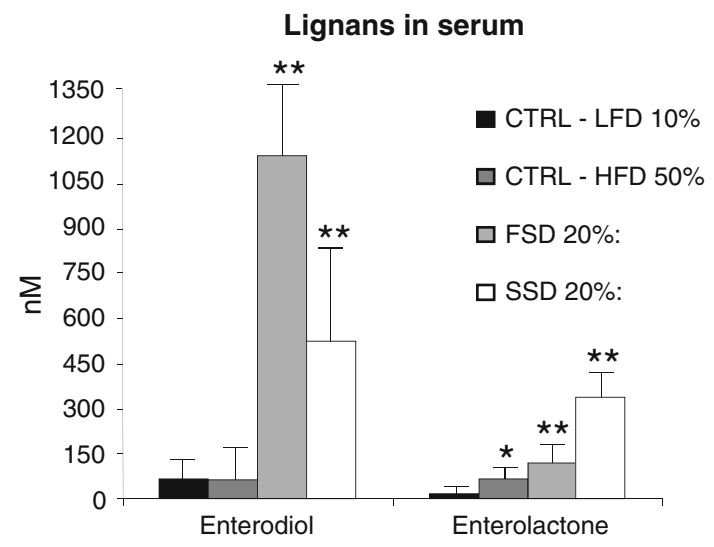

Fig. 5 Serum levels of enterodiol and enterolactone. Serum levels of ENL and END were measured by HPLC-MS/MS. Values are expressed as $\mathrm{nM}$ of substance in serum. The experiments were repeated twice with five mice for each group. Bars represent the average \pm SEM. $* p<0.05$ versus HFD, $* * p<0.001$ versus HFD

adipocyte signaling. Relative mRNA quantification for specific genes was based on TaqMan microfluidic cards and was normalized to the expression of $18 \mathrm{~S}$ reference gene relative quantification.

The genes that were found to be modulated, when compared with HFD in our assays, codify for members of the glucose metabolism [insulin receptor substrate-1 (Irs1), melanocortin receptor $4(\mathrm{Mc} 4 \mathrm{r})$, insulin-like growth factor 2 (Igf2), IGF-binding protein-5 (Igfbp5)], adipocyte metabolism [leptin (Lep), lipin 2 (Lpin2), phospholipid transfer protein (Pltp), acetyl-CoA carboxylase- $\alpha$ (Acaca), acyl-CoA dehydrogenase long chain (Acadl), adiponectin (Adipoq), apolipoprotein C2 (Apoc2), fatty acid-binding 
Fig. 6 Changes in metabolic pathways in the epididymal fat. Analysis of the gene expression patterns in epididymal fat. Relative mRNA quantification for specific genes was based on TaqMan, LDA microfluidic cards. The expression of sets of genes involved in

a inflammation, b insulin resistance/glucose metabolism, c adipose metabolism, $\mathbf{d}$ nuclear receptors was quantified. The expression of target genes was normalized to the expression of $18 \mathrm{~S}$ reference gene (relative quantification). Mice were treated with HFD or HFD plus SSD or plus FSD. Vehicle (dark gray bars), sesame (light gray bars), flaxseed (white bars). Values represent the fold induction over the control (LFD). The experiments were in triplicate. Bars represent the average \pm SEM. $* p<0.05$ versus $\mathrm{HFD}, * * p<0.001$ versus HFD
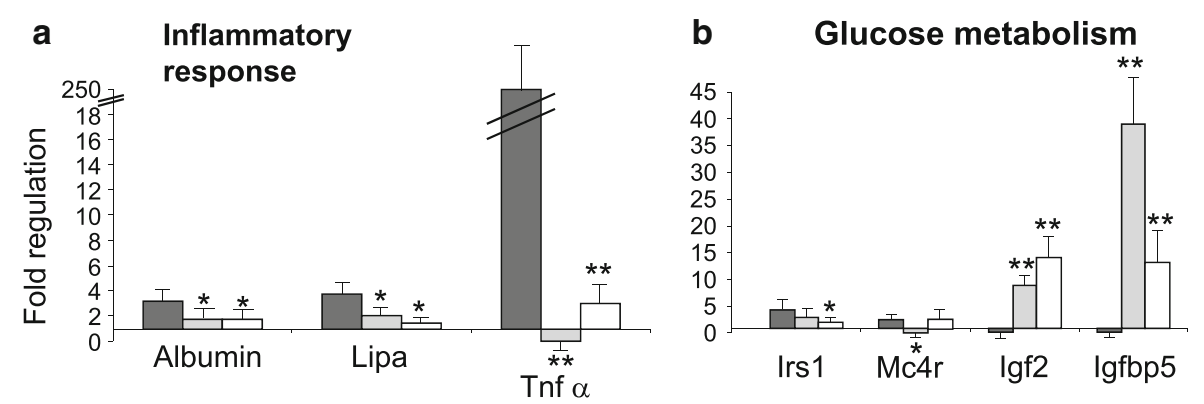

c
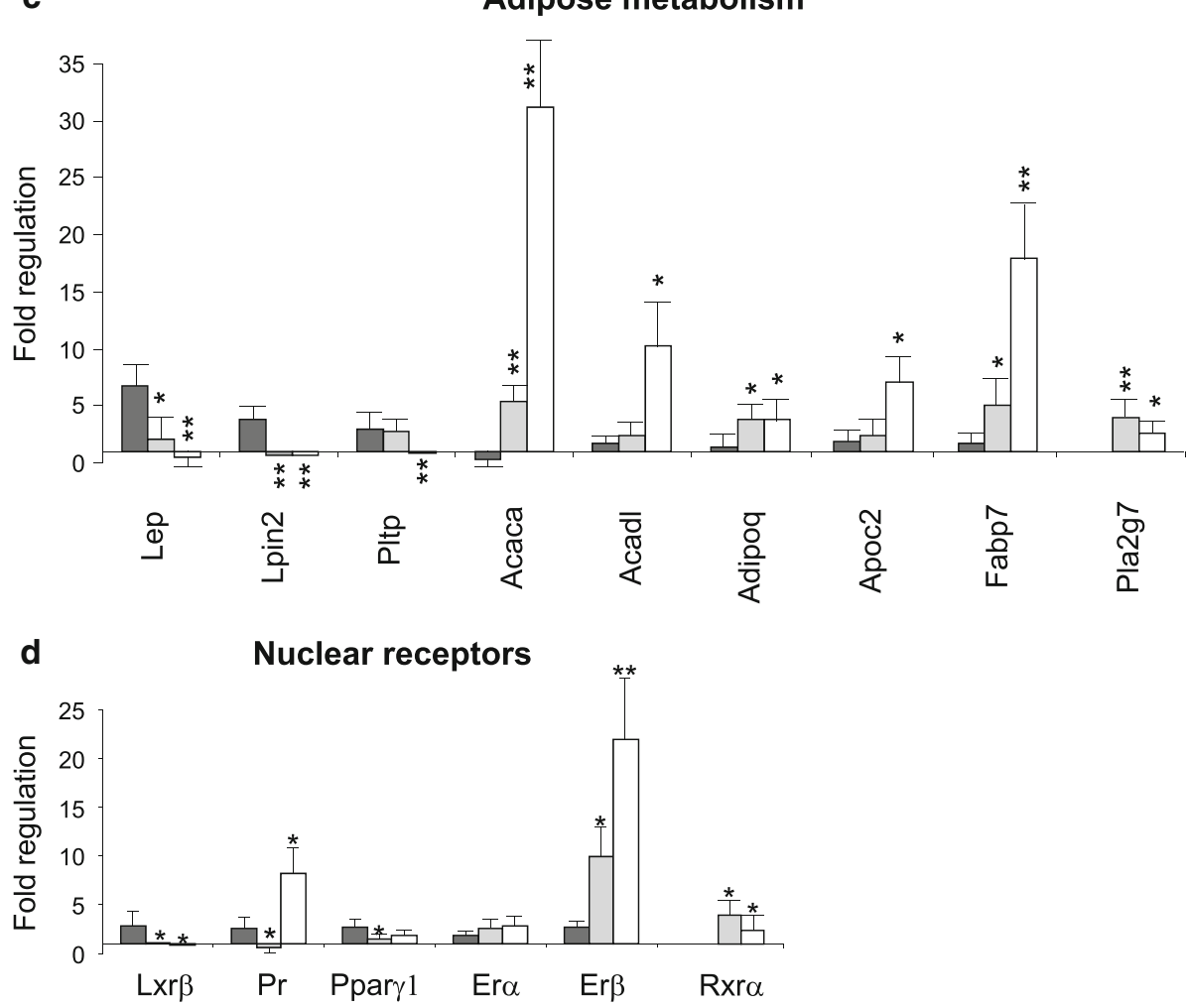

protein 7 (Fabp7), phospholipase A2 group 7 (Pla2g7)] and inflammation [tumor necrosis factor alpha (TNF $\alpha$ ), Inflammatory response lipoate synthase (Lipa) and albumin] (Fig. 6). The expression of genes involved in inflammatory response, Albumin and Lipa were significantly down-regulated by diet containing oilseeds, interestingly a consistent up-regulation (250-fold) of the inflammatory mediator TNF $\alpha$ caused by the HFD and its inhibition down to basal levels by both the SSD and FSD diets, was observed (Fig. 6a).The genes regarding glucose metabolism were regulated in different manner; Irs1 was significantly down-regulated with FSD, while Mc4r by SSD; Igf2 and Igfbp5 both augmented their expression, the first one in more evident mode by FSD and the second one by SSD. Among the genes involved in adipose metabolism Lep and Lpin2 showed inhibition of the expression both SSD and FSD; Acaca, Adipoq, Fabp7 and Pla2g7 were up- regulated by SSD and FSD, while Acadl and ApoC2 augmented significantly their expression only by FSD. Sesame and flaxseed are very rich in lignans that have been shown to act through the activation of NRs; thus, we also measured the regulation of NRs involved in metabolic cell functions [estrogen receptor alpha (Er $\alpha)$, estrogen receptor beta $(\operatorname{Er} \beta)$, peroxisome proliferator-activated receptor gamma 1 (Ppar 1$)$, progesterone receptor $(\operatorname{Pr})$, cholesterolsensing nuclear receptor $(\operatorname{Lxr} \beta)$, retinoidX receptor alpha $(\operatorname{Rxr} \alpha)]$. Interestingly, Er $\alpha$, and much more strongly $\operatorname{Er} \beta$, was up-regulated by flaxseed and to a lesser extent by sesame, Pr was up-regulated by FSD, but down-regulated with SSD. Typically regarded as key NRs for metabolic signaling in fat and liver cells, as $\operatorname{Lxr} \beta$ and with smaller effect Ppar $\gamma 1$, were less expressed, while Rxr $\alpha$ was upregulated, with slightly greater effect by sesame compared with flaxseed (Fig. 6d). 
Fig. 7 Effect of lignans on 3T3-L1 differentiation. 3T3-L1 cells were maintained in DMEM containing $10 \%$ calf serum. Two days after reaching confluence, the cells were treated for $48 \mathrm{~h}$ with vehicle (ctr) or the indicated lignans: a PIN, b CLAR, c LAR, d SEC and $\mathrm{e}$ SES in the basal medium (ctr-, BAS) or in the differentiation medium (ctr+, MDI). The cells received fresh medium every $48 \mathrm{~h}$. On the day 9 after treatment, lipid content was measured as described in "Materials and methods". Ordinate value represents the lipid content expressed as \% of the control. Each value is the mean \pm SD of three different determinations. ${ }^{\mathrm{a}} p<0.05$ versus ctr,$-{ }^{\mathrm{b}} p<0.001$ versus ctr,$-{ }^{\mathrm{c}} p<0.05$ versus $\mathrm{ctr}+$, ${ }^{\mathrm{d}} p<0.001$ versus $\mathrm{ctr}+$
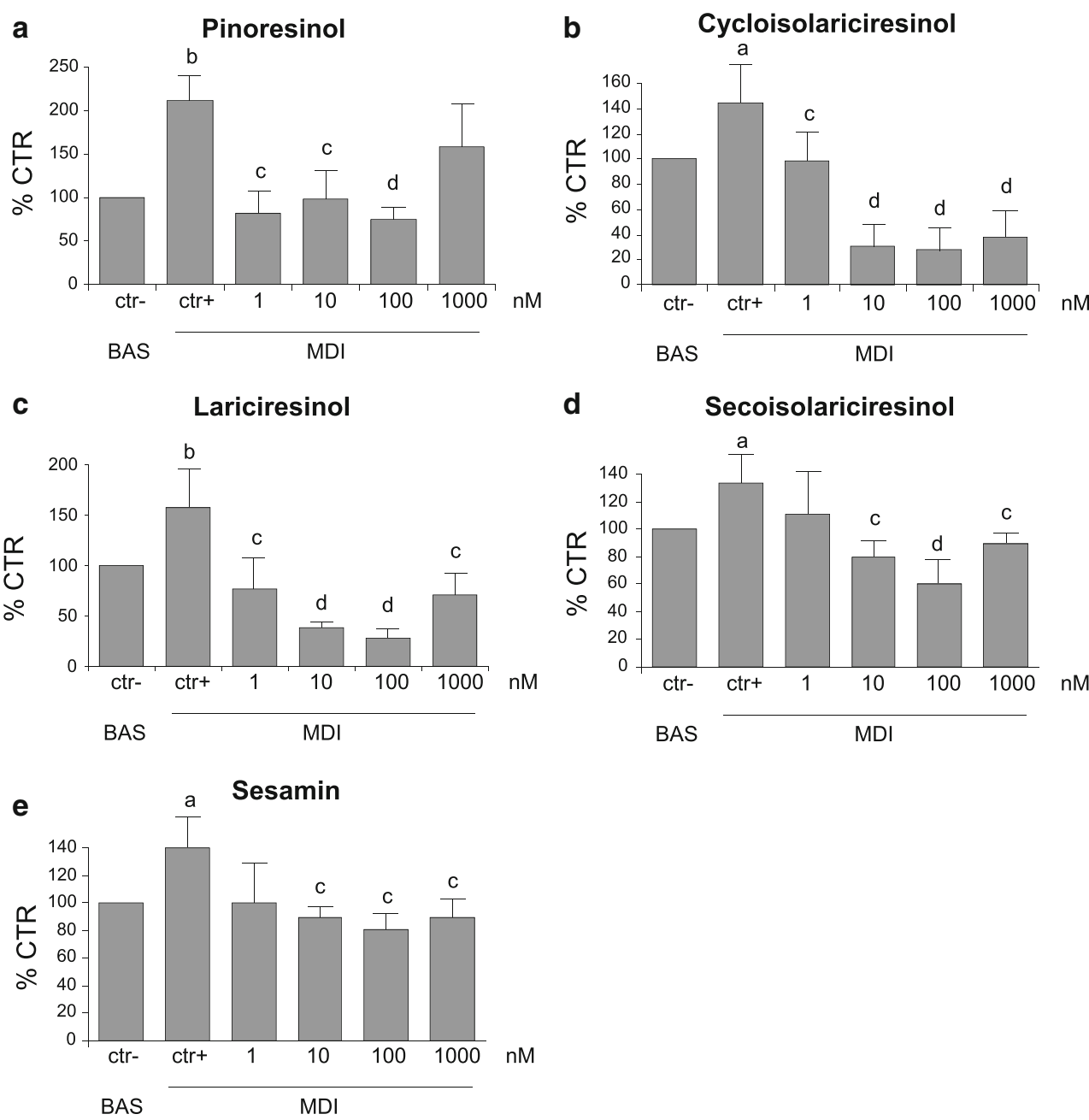

d
Effects of lignans on 3T3-L1 differentiation

The in vivo results indicate that sesame and flaxseed are antiadipogenic and anti-inflammatory foods. Lignans compose about $0.5-1 \%$ of the compounds present in these oilseeds (w/w) and are the most abundant polyphenols. According to our measurements (see "Materials and methods" section, Table 2) and to the literature [38], SEC and CLAR are mostly abundant in flaxseed and SES, LAR and PIN abundant in sesame (Table 3). Being aware of the fact that several other compounds present in these oilseeds may play an antiadipogenic role (omega-3, fiber, vitamins, etc.), we tested in vitro the contribution of both hydrophilic (SEC, CLAR, LAR, PIN) and lipophilic (SES) lignans as single molecules on the 3T3-L1 in vitro model of adipocyte cell differentiation. Cells were treated for $48 \mathrm{~h}$ with vehicle only (ctr) or different lignans (as single molecules) in BAS or in the MDI. On the day 9 after treatment, lipid content was measured by the adipogenesis assay. All the lignans tested were effective, although to a different extent in reducing lipid content. Some (PIN, LAR, CLAR) already at
nM doses confirming their antiadipogenic role (Fig. 7). We did not observe signs of cell toxicity at the used doses.

\section{Discussion}

In this study, we show that supplementation of HFD with $20 \%$ sesame or flaxseed flour significantly decreases the fat mass in C57BL/6J male mice and to a lesser extent also whole body weight, although this change did not reach significance. This effect was observed already after 2 weeks from the beginning of the treatments, while some difference in body weights started to be visible at 30 days. A clear decrease in the fat mass was also confirmed by the analysis of isolated epididymal and renal fat pads, by the measurement of the adipocyte size and by a decrease in liver steatosis. In mice, the supplemented diets led to an increase in ENL and END blood levels, indicating that the lignans present in these seeds were absorbed and metabolized and could be the contributors to the amelioration of MetS, as observed in the treated mice. The changes in 
adipose mass were associated with changes in insulin sensitivity, which was enhanced by both SSD and FSD diets and correlated with the increased levels of ENL and END. Twenty percent of sesame or flaxseed in the experimental diets used might be considered a high amount for typical western diets. However, if consistent amount of sesame in the order of tens of grams/meal is consumed, it might be close to human intake when consuming Middle Eastern diets, where sesame can be eaten in form of spread (tahina) or dietary oil [35], although the form of the sesame preparations may affect the absorption of lignans [41]. Flaxseed can also be consumed at higher amount in far eastern diets as boiled seeds and as flour in bread or biscuits [36]. Sesame and flaxseed contain 42.9 and $36 \%$ fat, respectively (see Table 2), which were considered in our calculations to have final isocaloric diets. We believe that the fat component in the total diet is important to make the lignan absorbable and bioavailable, since most of the lignans in sesame are lipophilic. A few authors who used defatted sesame or flaxseed reported that also non-lipophilic components may improve lipid profiles in experimental animals [42-44], although the results were not supported by other studies [45]. In this study, the amount of the ENL and END metabolites found in serum of our mice at the end of the experiments was in line with the concentrations found in serum of people consuming flaxseed or sesame as whole seeds or flours [46, 47], thus showing that our diets supplementation simulated a real dietary intake.

Beyond these systemic actions, SSD and FSD diets showed profound effects on metabolic parameters through the regulation of gene pathways controlling glucose and adipose metabolism, inflammation and nuclear receptor signaling in visceral fat. Changes in adipose metabolism were evidenced at molecular level through the measurement of the expression of related genes. Leptin and Lpin2 were inhibited by the oilseeds, while the expression of Pltp was decreased in FSD but not with SSD. The genes Acaca, Adiponectin, Fabp7 and Pla2g7 were induced, while the expression of Acadl, Apoc2 was increased at substantial level only in FSD. Among the induced genes, adiponectin was up-regulated threefold and fourfold. Adiponectin levels have been shown to be associated with insulin-like growth factor-binding protein-5 (IGFBP-5), which modulates the insulin growth factor (IGF) signaling pathway in human subjects [48]. IGFs are important determinants of metabolic functions; thus, the recent identification of modulators of IGF bioactivity is of high interest. A major regulatory action is exerted by six IGF-binding proteins (IGFBP-1 to 6), which show high affinity for IGFs [49, 50]. The IGF/IGFBP complexes prolong the half-lives of IGFs and thus may buffer the potential hypoglycemic effects that could result from high concentrations of circulating unbound IGFs [51]. IGFBP-5 is thus a key gene of glucose metabolism and has been shown to be associated with control of adiposity and is supposed to mediate a mechanism used to limit further fat gain [50]. In our experiments, IGFBP-5, as well as IGF-2, is strongly up-regulated by both the supplemented diets. These results point out the importance of compounds present in oilseeds in the control of glucose metabolism through IGFs and IGFBPs, stimulating further research aimed at providing detailed mechanistic insights.

The positive and negative association, respectively, of leptin and adiponectin expression with fat mass is well known [52]. The variations on adipokines expression in mice fed the oilseed-supplemented diets followed this trend. However, the effects of oilseed on the metabolic parameters analyzed are not uniform in the literature. In a work performed in rabbits [53] reported a flaxseeddependent induction of leptin, which positively correlated with levels of alpha linolenic acid (ALA) and inversely with atherosclerosis. These apparently contrasting associations underline the need for further research on the effects of dietary oilseeds on metabolic regulation.

Different nuclear receptors mediate the cell response to chemicals contained in food. Among these, the estrogen receptors $E R \alpha$ and $E R \beta$ have been shown to be activated by the mammalian lignans ENL and END [31, 54]. We here found that ER expression is induced in epididymal fat by sesame and flaxseeds, suggesting that their effect on fat mass deposition might have been produced through a mechanism that involves an estradiol-mimicking action. A stronger induction was observed for ER $\beta$, which is actually the ER isotype more responsive to phytoestrogenic compounds [55]. However, in light of the most recent progresses in the area of the study of natural ligands for the ERs from nutritional sources, the term "phytoestrogen" appears to be inadequate or poorly representative of the actual activity of the lignans, when considering metabolic functions as functional targets. The reason is that it is becoming frequent to observe that the same molecules that bind and activate the ERs, also bind and activate other NRs that may play opposite actions on the regulation of target genes (i.e., PPAR $\gamma$ ) and activate NR cross-talks with outcomes that are not clear [31, 56, 57]. An example of a lignan that binds the PPARs is macelignan $[58,59]$, which has been determined as a dual ligand for PPAR $\alpha / \gamma$ receptors. Macelignan improves insulin sensitivity in obese diabetic $(\mathrm{db} / \mathrm{db})$ mice and increases insulin secretion in the $\beta$-cell line MIN6, highlightening lignans as potential regulators of insulin release [60]. The mechanism underlying the coexisting activities of lignans as estrogen mimics, and at the same time, regulators of other NRs, such as PPARs, and LXRs, remain an open issue. Through a large computer-based screening of lignans using in silico techniques, compounds that may bind to other NRs have been selected. 
Using the structure of the ligand-binding domain of the LXR receptor (1PQ8, 1PQ6, 1PQC, 1UPV) [61], two lignans that display all characteristics of high-affinity ligands, MR and Secoisolariciresinol esquilignan Diglycoside (SDG), have been identified. In cell-dependent assays, MR and SDG were able to activate the expression of several LXR regulated target genes, both in colon and in liver cells (personal communication). Both LXR $\beta$ and PPAR $\gamma$ are down-regulated by sesame and flaxseed in the liver and adipocytes, respectively, suggesting an effect on the synthesis of triglycerides and adipocyte differentiation. Last but not least, all mentioned NRs are involved in decreasing the inflammation process through inhibition of inflammatory pathways/genes. Adipose accumulation is associated with increase expression of inflammatory genes. $\mathrm{TNF} \alpha$ showed a strong induction (up to 250 -fold) by the high-fat diet. When the oilseeds were added to the high-fat diet, they restored the level of TNF $\alpha$ expression down to the level found in mice fed the low-fat $(10 \%)$ diet, indicating an efficient amelioration of the diet-induced inflammation. Activated ERs, PPARs and LXRs are efficient inhibitors of NF-kB [62-64], suggesting that the antiinflammatory activity of lignans (as evidenced in Fig. 5) might also involve these NRs.

Here, we show that lignans, which are the most abundant polyphenols $(1 \% \mathrm{w} / \mathrm{w})$ (Table 3$)$ in the oilseeds sesame and flaxseed, are functional components. To get insights into their activity on fat cells, we studied a few lignans found to be abundant in flaxseed and sesame at range of doses that are consistent with those obtained through the diet (real-life doses). Most of the tested lignans were able to inhibit the induced adipogenesis in 3T3-L1 cells, although with a different efficiency. CLAR, LAR and PIN, the last one with less clear effect, were the most efficient, being active at the lowest doses utilized (1-10 nM range), while SEC and SES started to be active at $10 \mathrm{nM}$ showing a consistent potential for all these compounds on fat cell differentiation. Although these in vitro data support a role of the lignans in producing the effects observed in vivo, beyond the lignans, sesame and flaxseed contain consistent amounts of fibers, heterogeneous chemicals and functional compounds that may have contributed to the effects observed in vivo. The omega-3 fatty acid, ALA, is the most abundant fatty acid in flaxseed, and it is known to play a role in the regulation of leptin blood levels [53].

Impressive advances have been seen in the last years with regard to the identification of mechanisms of action for the most thoroughly investigated dietary polyphenols (lignans, stilbenes, isoflavones, etc.), and most of their health-related effects have been attributed to their activity as antioxidants $[29,30]$. A certain amount of data are now becoming available on the activity of these compounds at doses lower than those required to exert antioxidant activities, but sufficient to activate fundamental cell pathway-regulating metabolic functions $[18,19,22,65,66]$. Thus, the understanding of the possible health effect of lignans on the pathophysiological model of MetS has to go through the comprehension of their action as regulators of key factors that are central to metabolic pathway-regulating fat biosynthesis, fat storage and accumulation, glucose homeostasis, insulin biosynthesis and secretion, insulin sensitivity, cholesterol biosynthesis and secretion, and low chronic inflammation, which is the underlying contributor to the worsening of adipose metabolism and function [67, 68].

\section{Conclusions}

In conclusion, sesame and flaxseed show the properties of functional foods effective in ameliorating metabolic parameters that are altered in the MetS. The lignans represent one of the major groups of natural plant chemicals recommended to the consumer for their hormone-mimicking activities and amelioration of metabolic parameters, but a clear understanding of their mechanisms on health is still lacking. Nevertheless, lignan-based nutraceuticals are already on the market, indicating that this class of compounds deserves an urgent, multidisciplinary research to validate their healthy properties.

Acknowledgments We thank Deborah Bordiga for histochemical analysis and Alessandro Bulla and Francesca Piazza for English writing and editing assistance. This work was supported in part by European Union Grants QLK4-CT-2002-02221 (EDERA) and LSHBCT-2006-037168 (EXERA).

Conflict of interest On behalf of all authors, the corresponding author states that there is no conflict of interest.

\section{References}

1. Milder IE, Feskens EJ, Arts IC, Bueno de Mesquita HB, Hollman PC, Kromhout D (2009) Intake of the plant lignans secoisolariciresinol, matairesinol, lariciresinol, and pinoresinol in Dutch men and women. J Nutr 135:1202-1207

2. Ayres DC, Loike JD (1990) Lignans: chemical, biological and clinical properties. Cambridge University Press, Cambridge, MA

3. Smeds AI, Eklund PC, Sjöholm RE, Willför SM, Nishibe S, Deyama T, Holmbom BR (2007) Quantification of a broad spectrum of lignans in cereals, oilseeds, and nuts. J Agric Food Chem 55:1337-1346

4. Webb AL, McCullough ML (2005) Dietary lignans: potential role in cancer prevention. Nutr Cancer 51:117-131

5. Dixon RA (2004) Phytoestrogens. Annu Rev Plant Biol 55:225-261

6. Mazur W, Wähälä K, Rasku S, Makkonen A, Hase T, Adlercreutz $H$ (1999) Lignans and isoflavonoid polyphenols in tea and coffee. J Med Food 2:199-202 
7. Adlercreutz H (2007) Lignans and human health. Crit Rev Clin Lab Sci 44:483-525

8. Fletcher RJ (2003) Food sources of phyto-oestrogens and their precursors in Europe. Br J Nutr 89(1):S39-S43

9. Valsta LM, Kilkkinen A, Mazur W, Nurmi T, Lampi AM, Ovaskainen ML, Korhonen T, Adlercreutz H, Pietinen P (2003) Phyto-oestrogen database of foods and average intake in Finland. Br J Nutr 89:31-38

10. Touillaud MS, Thiébaut AC, Fournier A, Niravong M, BoutronRuault MC, Clavel-Chapelon F (2007) Dietary lignan intake and postmenopausal breast cancer risk by estrogen and progesterone receptor status. J Natl Cancer Inst 99:475-486

11. Moreno-Franco B, García-González Á, Montero-Bravo AM, Iglesias-Gutiérrez E, Úbeda N, Maroto-Núñez L, Adlercreutz H, Peñalvo JL (2011) Dietary alkylresorcinols and lignans in the Spanish diet: development of the alignia database. J Agric Food Chem 59:9827-9834

12. Knust U, Spiegelhalder B, Strowitzki T, Owen RW (2006) Contribution of linseed intake to urine and serum enterolignan levels in German females: a randomised controlled intervention trial. Food Chem Toxicol 44:1057-1064

13. Eeckhaut E, Struijs K, Possemiers S, Vincken JP, Keukeleire DD, Verstraete W (2008) Metabolism of the lignan macromolecule into enterolignans in the gastrointestinal lumen as determined in the simulator of the human intestinal microbial ecosystem. J Agric Food Chem 56:4806-4812

14. Wang CZ, Ma XQ, Yang DH, Guo ZR, Liu GR, Zhao GX, Tang J, Zhang YN, Ma M, Cai SQ, Ku BS, Liu SL (2010) Production of enterodiol from defatted flaxseeds through biotransformation by human intestinal bacteria. BMC Microbiol 16:115

15. Suzuki R, Rylander-Rudqvist T, Saji S, Bergkvist L, Adlercreutz H, Wolk A (2008) Dietary lignans and postmenopausal breast cancer risk by oestrogen receptor status: a prospective cohort study of Swedish women. Br J Cancer 98:636-640

16. Hallmans G, Zhang JX, Lundin E, Stattin P, Johansson A, Johansson I, Hultén K, Winkvist A, Aman P, Lenner P, Adlercreutz $\mathrm{H}$ (2003) Rye, lignans and human health. Proc Nutr Soc 62:193-199

17. Bloedon LT, Balikai S, Chittams J, Cunnane SC, Berlin JA, Rader DJ, Szapary PO (2008) Flaxseed and cardiovascular risk factors: results from a double blind, randomized, controlled clinical trial. J Am Coll Nutr 27:65-74

18. Patade A, Devareddy L, Lucas EA, Korlagunta K, Daggy BP, Arjmandi BH (2008) Flaxseed reduces total and LDL cholesterol concentrations in Native American postmenopausal women. J Womens Health (Larchmt) 17:355-366

19. Pan A, Yu D, Demark-Wahnefried W, Franco OH, Lin X (2009) Meta-analysis of the effects of flaxseed interventions on blood lipids. Am J Clin Nutr 90:288-297

20. Sturgeon SR, Volpe SL, Puleo E, Bertone-Johnson ER, Heersink J, Sabelawski S, Wahala K, Bigelow C, Kurzer MS (2010) Effect of flaxseed consumption on urinary levels of estrogen metabolites in postmenopausal women. Nutr Cancer 62:175-180

21. Sturgeon SR, Heersink JL, Volpe SL, Bertone-Johnson ER, Puleo E, Stanczyk FZ, Sabelawski S, Wahala K, Kurzer MS, Bigelow C (2008) Effect of dietary flaxseed on serum levels of estrogens and androgens in postmenopausal women. Nutr Cancer 60:612-618

22. Hallund J, Tetens I, Bügel S, Tholstrup T, Bruun JM (2008) The effect of a lignan complex isolated from flaxseed on inflammation markers in healthy postmenopausal women. Nutr Metab Cardiovasc Dis 18:497-502

23. Prasad K (2010) Natural products in regression and slowing of progression of atherosclerosis. Curr Pharm Biotechnol 11:794800

24. Prasad K (2009) Flaxseed and cardiovascular health. J Cardiovasc Pharmacol 54:369-377
25. Prasad K (2007) A study on regression of hypercholesterolemic atherosclerosis in rabbits by flax lignan complex. J Cardiovasc Pharmacol Ther 12:304-313

26. Penumathsa SV, Koneru S, Thirunavukkarasu M, Zhan L, Prasad K, Maulik N (2007) Secoisolariciresinol diglucoside: relevance to angiogenesis and cardioprotection against ischemia-reperfusion injury. J Pharmacol Exp Ther 320:951-959

27. Dodin S, Cunnane SC, Mâsse B, Lemay A, Jacques H, Asselin G, Tremblay-Mercier J, Marc I, Lamarche B, Légaré F, Forest JC (2008) Flaxseed on cardiovascular disease markers in healthy menopausal women: a randomized, double-blind, placebo-controlled trial. Nutrition 24:23-30

28. Zhang S, Ho SC (2005) Meta-analysis of the effects of soy protein containing isoflavones on the lipid profile. Am J Clin Nutr 81:397-408

29. Wu WH, Kang YP, Wang NH, Jou HJ, Wang TA (2006) Sesame ingestion affects sex hormones, antioxidant status, and blood lipids in postmenopausal women. J Nutr 136:1270-1275

30. Carreau C, Flouriot G, Bennetau-Pelissero C, Potier M (2008) Enterodiol and enterolactone, two major diet-derived polyphenol metabolites have different impact on ERalpha transcriptional activation in human breast cancer cells. J Steroid Biochem Mol Biol 110:176-185

31. Penttinen P, Jaehrling J, Damdimopoulos AE, Inzunza J, Lemmen JG, van der Saag P, Pettersson K, Gauglitz G, Mäkelä S, Pongratz I (2007) Diet-derived polyphenol metabolite enterolactone is a tissue-specific estrogen receptor activator. Endocrinology 148:4875-4886

32. Pan A, Sun J, Chen Y, Ye X, Li H, Yu Z, Wang Y, Gu W, Zhang X, Chen X, Demark-Wahnefried W, Liu Y, Lin X (2007) Effects of a flaxseed-derived lignan supplement in type 2 diabetic patients: a randomized, double-blind, cross-over trial. PLoS One 2:e1148

33. Salas-Salvadó J, Fernández-Ballart J, Ros E, Martínez-González MA, Fitó M, Estruch R, Corella D, Fiol M, Gómez-Gracia E, Arós F, Flores G, Lapetra J, Lamuela-Raventós R, Ruiz-Gutiérrez V, Bulló M, Basora J, Covas MI (2008) Effect of a Mediterranean diet supplemented with nuts on metabolic syndrome status: oneyear results of the PREDIMED randomized trial. Arch Intern Med 168:2449-2458

34. Carlson JJ, Joey RD, Eisenmann C, Norman GJ, Ortiz KA, Young PC (2011) Dietary Fiber and nutrient density are inversely associated with the metabolic syndrome in US adolescents. J Am Diet Assoc 111:1688-1695

35. Namiki M (2007) Nutraceutical functions of sesame: a review. Crit Rev Food Sci Nutr 47:651-673

36. Muir AD, Westcott ND (2000) Quantitation of the lignan secoisolariciresinol diglucoside in baked goods containing flax seed or flax meal. J Agric Food Chem 48:4048-4052

37. Grougnet R, Magiatis $\mathrm{P}$, Mitaku S, Terzis A, Tillequin F, Skaltsounis AL (2006) New lignans from the perisperm of Sesamum indicum. J Agric Food Chem 54:7570-7574

38. Milder IE, Arts IC, van de Putte B, Venema DP, Hollman PC (2005) Lignan contents of Dutch plant foods: a database including lariciresinol, pinoresinol, secoisolariciresinol and matairesinol. Br J Nutr 93:393-402

39. Smeds AI, Hakala K, Hurmerinta TT, Kortela L, Saarinen NM, Mäkelä SI (2006) Determination of plant and enterolignans in human serum by high-performance liquid chromatography with tandem mass spectrometric detection. J Pharm Biomed Anal 7:898-905

40. Moazzami AA, Kamal-Eldin A (2006) Sesame seed is a rich source of dietary lignans. JAOCS 83:719-723

41. Papadakis EN, Lazarou D, Grougnet R, Magiatis P, Skaltsounis AL, Papadopoulou-Mourkidou E, Papadopoulos AI (2008) Effect of the form of the sesame-based diet on the absorption of lignans. Br J Nutr 100:1213-1219 
42. Wikul A, Damsud T, Kataoka K, Phuwapraisirisan P (2012) (+)Pinoresinol is a putative hypoglycemic agent in defatted sesame (Sesamum indicum) seeds though inhibiting $\alpha$-glucosidase. Bioorg Med Chem Lett 22:5215-5217

43. Biswas A, Dhar P, Ghosh S (2010) Antihyperlipidemic effect of sesame (Sesamum indicum L.) protein isolate in rats fed a normal and high cholesterol diet. J Food Sci 75:H274-H279

44. Jenkins DJ, Kendall CW, Vidgen E, Agarwal S, Rao AV, Rosenberg RS, Diamandis EP, Novokmet R, Mehling CC, Perera T, Griffin LC, Cunnane SC (1999) Health aspects of partially defatted flaxseed, including effects on serum lipids, oxidative measures, and ex vivo androgen and progestin activity: a controlled crossover trial. Am J Clin Nutr 69:395-402

45. Babu US, Mitchell GV, Wiesenfeld P, Jenkins MY, Gowda H (2000) Nutritional and hematological impact of dietary flaxseed and defatted flaxseed meal in rats. Int $\mathbf{J}$ Food Sci Nutr 51:109-117

46. Edel AL, Aliani M, Pierce GN (2013) Supported liquid extraction in the quantitation of plasma enterolignans using isotope dilution GC/MS with application to flaxseed consumption in healthy adults. J Chromatogr B Analyt Technol Biomed Life Sci 912:24-32

47. Wu JH, Hodgson JM, Puddey IB, Belski R, Burke V, Croft KD (2009) Sesame supplementation does not improve cardiovascular disease risk markers in overweight men and women. Nutr Metab Cardiovasc Dis 19:774-780

48. Kallio P, Tolppanen AM, Kolehmainen M, Poutanen K, Lindström J, Tuomilehto J, Kuulasmaa T, Kuusisto J, Pulkkinen L, Uusitupa M (2009) Association of sequence variations in the gene encoding insulin-like growth factor binding protein 5 with adiponectin. Int J Obes (Lond) 33:80-88

49. Ning Y, Schuller AG, Bradshaw S, Rotwein P, Ludwig T, Frystyk J, Pintar JE (2006) Diminished growth and enhanced glucose metabolism in triple knockout mice containing mutations of insulin-like growth factor binding protein-3, -4, and -5. Mol Endocrinol 2:2173-2186

50. Gleason CE, Ning Y, Cominski TP, Gupta R, Kaestner KH, Pintar JE, Birnbaum MJ (2010) Role of insulin-like growth factor-binding protein 5 (IGFBP5) in organismal and pancreatic beta-cell growth. Mol Endocrinol 24:178-192

51. Di Cola G, Cool MH, Accili D (1997) Hypoglycemic effect of insulin-like growth factor-1 in mice lacking insulin receptors. J Clin Invest 99:2538-2544

52. Ramachandrappa S, Farooqi IS (2011) Genetic approaches to understanding human obesity. J Clin Invest 121:2080-2086

53. McCullough RS, Edel AL, Bassett CM, Lavallée RK, Dibrov E, Blackwood DP, Ander BP, Pierce GN (2011) The alpha linolenic acid content of flaxseed is associated with an induction of adipose leptin expression. Lipids 6:1043-1052

54. Woting A, Clavel T, Loh G, Blaut M (2010) Bacterial transformation of dietary lignans in gnotobiotic rats. FEMS Microbiol Ecol 72:507-514

55. Gustafsson JA (2006) Comments to the paper "tools to evaluate estrogenic potency of dietary phytoestrogens: a consensus paper from the EU Thematic Network "Phytohealth" (QLKI-20022453)". Genes Nutr 1:159-160

56. Fukumitsu S, Aida K, Ueno N, Ozawa S, Takahashi Y, Kobori M (2008) Flaxseed lignan attenuates high-fat diet-induced fat accumulation and induces adiponectin expression in mice. $\mathrm{Br} \mathbf{J}$ Nutr 100:669-676

57. Dip R, Lenz S, Antignac JP, Le Bizec B, Gmuender H, Naegeli H (2008) Global gene expression profiles induced by phytoestrogens in human breast cancer cells. Endocr Relat Cancer $1: 161-173$

58. Yang XW, Huang X, Ahmat M (2008) New neolignan from seed of Myristica fragrans. Zhongguo Zhong Yao Za Zhi 33:397-402

59. Filleur F, Pouget C, Allais DP, Kaouadji M, Chulia AJ (2002) Lignans and neolignans from Myristica argentea Warb. Nat Prod Lett $16: 1-7$

60. Han KL, Choi JS, Lee JY, Song J, Joe MK, Jung MH, Hwang JK (2008) Therapeutic potential of peroxisome proliferators-activated receptor-alpha/gamma dual agonist with alleviation of endoplasmic reticulum stress for the treatment of diabetes. Diabetes $57: 737-745$

61. Malini N, Rajesh H, Berwal P, Phukan S, Balaji VN (2008) Analysis of crystal structures of LXRbeta in relation to plasticity of the ligand-binding domain upon ligand binding. Chem Biol Drug Des 71:140-154

62. Quaedackers ME, van den Brink CE, van der Saag PT, Tertoolen LG (2007) Direct interaction between estrogen receptor alpha and NF-kappaB in the nucleus of living cells. Mol Cell Endocrinol 273:42-50

63. Jennewein C, Kuhn AM, Schmidt MV, Meilladec-Jullig V, von Knethen A, Gonzalez FJ, Brüne B (2008) Sumoylation of peroxisome proliferator-activated receptor gamma by apoptotic cells prevents lipopolysaccharide-induced NCoR removal from kap$\mathrm{paB}$ binding sites mediating transrepression of proinflammatory cytokines. J Immunol 181:5646-5652

64. Chang L, Zhang Z, Li W, Dai J, Guan Y, Wang X (2007) Liver$\mathrm{X}$-receptor activator prevents homocysteine-induced production of $\mathrm{IgG}$ antibodies from murine B lymphocytes via the ROS-NFkappaB pathway. Biochem Biophys Res Commun 357:772-778

65. Penza M, Montani C, Romani A, Vignolini P, Pampaloni B, Tanini A, Brandi ML, Alonso-Magdalena P, Nadal A, Ottobrini L, Parolini O, Bignotti E, Calza S, Maggi A, Grigolato PG, Di Lorenzo D (2006) Genistein affects adipose tissue deposition in a dose-dependent and gender-specific manner. Endocrinology 147: 5740-5751

66. Montani C, Penza M, Jeremic M, Biasiotto G, La Sala G, De Felici M, Ciana P, Maggi A, Di Lorenzo D (2008) Genistein is an efficient estrogen in the whole-body throughout mouse development. Toxicol Sci 103:57-67

67. Abete I, Goyenechea E, Zulet MA, Martínez JA (2011) Obesity and metabolic syndrome: potential benefit from specific nutritional components. Nutr Metab Cardiovasc Dis 21:B1-B15

68. Onat A (2011) Metabolic syndrome: nature, therapeutic solutions and options. Expert Opin Pharmacother 12:1887-1900 